\title{
Fakta Kemanusiaan Dalam Novel Tentang Kamu Karya Tere Liye Yang Mencerminkan Sejarah PKI: Kajian Strukturalisme Genetik Lucien Goldmann
}

\author{
Ayu Nurmalayani', Burhanuddin' ${ }^{2}$, dan Johan Mahyudi ${ }^{3}$ \\ Program Pascasarjana Pendidikan Bahasa Indonesia FKIP Unram \\ email: ayurengganisa1la@gmail.com
}

\begin{abstract}
This research study aims to describe the reflection on the history of the PKI in Tere Lie's Novel About You. The focus of his description is human facts in novels that reflect the history of the PKI. This research is a descriptive qualitative study using genetic structuralism theory. The research data were collected using the document review method. Data were analyzed using structural genetic methods. Based on the results and discussion, it is known that the human facts in Tere Liye's novel About You reflect the dominant PKI history in the form of social facts, namely in the form of social, economic, and political relations. In this case, some are verbal and some are nonverbal. It can be concluded that: (1) Social facts in the form of social relations are reflected in the story of the kidnapping and massacre of kyai, kiyai families, and pesantrean pesantrean santri by Musoh and Latri because of their dissatisfaction with Ma'sum's financial policy, even though previously they were religious people of Kyai Ma' sum; (2) Social facts in the form of economic relations reflected in the story of the economic arrangement of the Islamic boarding schools which were used as tools to incite others to hate the leaders of the Islamic boarding schools and to carry out rebellions; and (3) social facts in the form of political relations reflected in the story of the communist movement in Indonesia in 1948-1965, the uncontrolled struggle for influence and power between the TNI and PKI political elites, and the spread of hateful words / slogans by the PKI group.
\end{abstract}

Keywords: Reflection, PKI History, Genetic Structuralism, And Human Facts

Abstrak. Penelitian ini betujuan untuk mendeskripsikan refleksi sejarah PKI dalam Novel Tentang Kати karya Tere Lie. Fokus pendeskripsiannya adalah fakta kemanusiaan dalam novel yang mencerminkan sejarah PKI. Penelitian ini merupakan penelitian kualitatif deskriptif menggunakan teori strukturalisme genetik. Data penelitian dikumpulkan dengan metode telaah dokumen. Data dianalisis dengan menggunakan metode struktural genetik. Berdasarkan hasil dan pembahasan, diketahui bahwa fakta kemanusiaan dalam novel Tentang Kamu karya Tere Liye yang mencerminkan sejarah PKI dominan berupa fakta sosial, yakni berupa hubungan sosial, ekonomi, dan politik. Dalam hal ini, ada yang berupa verbal dan ada pula yang berupa nonverbal. Disimpulkan bahwa: (1) Fakta sosial berupa hubungan sosial tercernin pada kisah penculikan dan pembantaian kiyai, keluarga kiyai, dan santri-santri pondok pesantrean oleh Musoh dan Latri karena ketidakpuasannya terhadap kebijakan kiayai Ma'sum, padahal sebelumnya mereka adalah orang kepercayaan kiyai Ma'sum; (2) Fakta sosial berupa hubungan ekonomi tercernin pada kisah pengaturan perekonomian pondok pesantren yang dijadikan alat untuk menghasut orang lain agar membenci pimpinan pondok pesantren dan melakukan pemberontakan; dan (3) Fakta sosial berupa hubungan politik tercernin pada kisah pergerakan faham komunis di Indonesia tahun 1948-1965, perebutan pengaruh dan kekuasaan anatar elit politik TNI dan PKI yang tak terkendali, dan penyebaran kata-kata/slogan kebencian oleh kelompok PKI.

Kata kunci: Refleksi, Sejarah PKI, Strukturalisme Genetik, Dan Fakta Kemanusiaan

\section{PENDAHULUAN}

Realita yang dimunculkan pengarang dalam karya-karyanya tidak lepas dari lingkungan sekitar dan masa lalunya. Realita ini diramu dalam kisah-kisah yang mampu menginspirasi pembaca. Kisah historis atau 
sejarah juga termasuk realita yang sering dimunculkan dalam sebuah karya sastra termasuk novel. Rokhman, (2008:23) menyatakan bahwa karya sastra tidak dapat dilepaskan dari kolektivitas dan konteks historis yang melahirkannya. Sejarah (historis) menjadi salah satu unsur yang menarik untuk diangkat menjadi latar dan tema sebuah novel. Selain mampu menuntun imajinasi, sejarah juga mampu membangun cara berpikir kritis dan kreatif karena darinya diperoleh refleksi kehidupan untuk perbaikan masa mendatang. Salah satunya adalah kisah (historis) yang menjadi latar sosial pada novel-novel Tere Liye.

Dalam novel-novelnya, Tere Liye banyak mengambil sejarah sebagai latar belakang penggambaran ceritanya. Tere Liye menyusun sederet kalimat yang dapat mewakili rentetan cerita sejarah masa silam dan dimunculkan kembali dalam bentuk cerita untuk diketahui pembaca pada zaman selanjutnya. Penulisan semacam ini juga dimaksudkan untuk dapat menawarkan berbagai nilai sejarah bagi pembaca. Hal ini dikarenakan nilai sejarah merupakan nilai yang dapat memberikan pemahaman bagi pembaca agar bisa belajar dari peristiwa masa lalu dalam menyikapi dilematika kehidupan masa kini.

Pada beberapa novel Tere Liye ditemukan sejumlah catatan sejarah bangsa Indonesia. Catatan-catatan sejarah ini dijadikan latar penceritaan kisah yang dibangun untuk menjelaskan sutau fenomena yang muncul pada aktivitas dan lingkungan pengarang. Tere Liye memanfaatkan catatan sejarah itu sebagai latar penceritaan dalam novelnya dengan maksud agar sejarah itu tidak hilang, terus dikenang, dan menjadi pembelajaran bagi generasi berikutnya. Catatan-catatan sejarah yang dikemas Tere Liye dengan gaya penceritaan anak muda menjadikan novel-novelnya menarik dan mendapat sambutan banyak kalangan. Misalnya. "Aku bergegas memperbaiki posisi duduk. Sudah pukul 17.15. Di Jimbaran itu berarti pukul 18.15. Berbilang menit lagi matahari akan tenggelam di sana (Liye, 2015: 6). Tetapi ya Tuhan, orang-orang jahat itu hanya butuh waktu satu detik untuk mengacak-acak seluruh kebahagiaan Rosie. Mengacak-acak semuanya. 00.00.00. Timer bom itu sempurna menyentuh angka nol (Liye, 2018:19). Ini adalah jejak-jejak sejarah Bom Bali. Pada novel Rindu, ditemukan penggunaan latar sejarah pelayaran pemberangkatan Haji dari Indonesia ke Tanah Suci sejak zaman penjajahan Belanda (Liye, 2014). Pada novel Tentang Кати (Liye, 2016) dan Anak Cahanya (Liye, 2018) ditemukan penggunaan latar sejarah Partai Komunis Indonesia (PKI) sebagai latar penceritaan. Pada novel Anak Cahanya, latar PKI yang diangkat adalah sejarah PKI di Sumatera, yang tidak menjadi catatan sejarah nasional karena tidak terdokumentasikan secara nasional pada buku-buku sejarah. Secara kuantitas, juga terdapat hanya pada sebagian kecil penggalan novel. Sebaliknya, pada novel Tentang Kamu, sejarah PKI yang digunakan sebagai latar penceritaannya terdokumentasikan sebagai catatan sejarah nasional bangsa. Lebih dari itu, secara kuantitas juga terdapat pada sebagian besar penggalan novel.

Sejarah PKI sebagai latar penceritaan novel Tentang Kamu dapat diungkap melalui tiga hal sesuai dengan pandangan teori strukturalisme generik. Ketiga hal dimaksud adalah fakta kemanusiaan, subjek kolektif, dan pandangan dunia (Goldmann dalam Faruk, 2014:56). Melalui tulisan ini akan disajikan hasil penelitian tentang sejarah PKI pada novel Tentang Kamu yang tercermin pada fakta kemanusiaan. Oleh karena itu, masalah yang dibahas melalui tulisan ini adalah bagaimanakah fakta kemanusiaan dalam novel Tentang Kamu karya Tere Liye yang mencerminkan sejarah PKI?

Strukturalisme dipandang sebagai pendekatan objektif, yakni pendekatan dalam penelitian sastra yang memusatkan perhatiannya pada otonomi sastra sebagai karya fiksi (Iswanto, 2003: 60). Analisis secara struktural memang menghasilkan suatu analisis yang objektif terhadap suatu karya. Namun demikian, strukturalisme mempunyai dua kelemahan, yaitu hanya melakukan penyelidikan terhadap unsur formal yang 
bertolak dari struktur bahasa dan hanya memperhatikan adanya sistem itu sendiri (Junus dalam Faruk, 2002: 16). Dalam konteks ini, analisis struktural merupakan salah satu kajian kesusastraan yang menitikberatkan hanya pada hubungan antarunsur pembangun karya sastra, berupa tema, penokohan, alur, pusat pengisahan, latar, dan sebagainya. Struktur karya sastra semisal novel merupakan sebuah totalitas makna, yang dibangun oleh unsur instrinsik dan ekstrinsik (Sitepu, 2009). Hal ini lazim dipandang sebagai makro sastra (Damono, 2009; Ratna, 2013). Oleh karena itu, analisis struktural perlu dilanjutkan dengan analisis sosiologi yang disebut dengan strukturalisme genetik.

Goldmann, filsuf dan sosiolog Prancis, pencetus teori strukturalisme genetik mengatakan bahwa seorang pengarang tidak mungkin mempunyai pandangan sendiri. Pada dasarnya, dia menyuarakan pandangan dunia suatu kelompok sosial, trans-individual subject (Fananie, 2000:117). Pandangan tersebut bukanlah suatu realitas, melainkan sesuatu yang hanya dapat dinyatakan secara imajinatif dan konseptual dalam bentuk karya sastra besar. Dengan kata lain, karya sastra yang besar oleh Goldmann dianggap sebagai fakta sosial dari trans-individual subject karena merupakan hasil aktivitas yang objeknya merupakan alam semesta dan kelompok manusia (Fananie,2000:118). Itulah sebabnya, pandangan dunia (worldview) yang tercermin dalam karya sastra terikat oleh ruang dan waktu yang menyebabkan ia bersifat historis. Hal inilah yang menjadikan teori Goldmann selalu menekankan pada latar belakang sejarah. Goldmann mempertegas kembali bahwa di samping hakikat karya sastra yang bersifat otonom, karya sastra tidak dapat terlepas dari unsur ekstrinsik karya sastra itu sendiri.

Berdasarkan anggapan di atas, menurut Goldmann, teori strukturalismegenetik memiliki dua kerangka besar. Pertama, hubungan antara makna suatu unsur dengan unsur lainnya dalam suatu karya sastra yang sama, dan kedua hubungan tersebut membentuk suatu jaring yang saling mengikat. Oleh karena itu, seorang pengarang pada dasarnya akan menyarankan pandangan dunia suatu kolektif. Pandangan tersebut bukan merupakan realitas melainkan suatu refleksi yang diungkap secara imajinatif (Endraswara, 2011: 56)

Goldmann (dalam Fernando, 2018) merumuskan penelitian strukturalisme genetik ke dalam tiga hal,yaitu: (1) penelitian terhadap karya sastra seharusnya dilihat sebagai satu kesatuan; (2) karyasastra yang diteliti mestinya karya sastra yang mengandung tegangan (tension) antara keragaman dan kesatuan dalam suatu keseluruhan (a coherent whole); (3) jika kesatuan telah ditemukan, kemudian dianalisis dalam hubungannya dengan latarbelakang sosial. Goldmenn membangun seperangkat kategori atau konsep yang saling berkaitan, yang melahirkan teori strukturalisme genetik. Salah satu kategori dimaksud adalah fakta kemanusiaan.

Sebuah karya tidak lahir secara serta merta melainkan melalui proses yang dilalui oleh pengarang. Kehidupan tokoh yang dituang pengarang dalam karyanya tak bisa lepas dari aktivitas subjek yang ada di dalamnya. Aktivitas-aktivitas ini merupakan fakta yang diolah pengarang dalam imajinasinya. Fakta ini terbentuk selain dari aktivitas imjinasi pengarang, juga dipengaruhi oleh aktvitas sosial pengarang sebagai anggota masyarakat. Seperti yang dikatakan Faruk bahwa fakta kemanusiaan merupakan segala hasil aktivitas atau perilaku manusia baik verbal maupun fisik, yang berusaha dipahami oleh ilmu pengetahuan. Fakta tersebut berwujud aktivitas sosial tertentu seperti sumbangan bencana alam, aktivitas politik tertentu seperti pemilu, maupun kreasi kultural seperti filsafat, seni rupa, seni musik, seni patung, dan seni sastra (Faruk, 2014: 57).

Meskipun fakta kemanusiaan berwujud macam-macam, tetapi pada hakikatnya fakta kemanusiaan dapat dibedakan menjadi dua macam yaitu, fakta individual dan fakta sosial. Fakta individual tidak mempunyai peranan dalam sejarah sedangkan fakta sosial sebaliknya. Menurut Faruk (2014: 57), fakta pertama hanya 
merupakan hasil dari prilaku libidinal seperti mimpi, tingkah laku orang gila, dan sebagainya. Sementara itu, fakta sosial memiliki dampak pada hubungan sosial, ekonomi, maupun politik antaranggota masyarakat. Faruk juga menjelaskan bahwa dalam teori strukturalisme-genetik, sebuah pernyataan yang dianggap sahih jika di dalamnya terkandung gambaran mengenai tata kehidupan yang bersistem dan terpadu, yang didasarkan pada sebuah landasan ontologis yang berupa kodrat keberadaan kenyataan itu dan pada landasan epistemologis yang berupa seperangkat gagasan sistematik mengenai cara memahami atau mengetahui kenyataan yang bersangkutan (Faruk, 2014: 56).

Berangkat dari pernyataan di atas dapat dikatakan bahwa fakta-fakta kemanusiaan merupakan respon-respon dari subjek kolektif atau individual, pembangunan suatu percobaan agar sesuai dengan inspirasi yang telah dibangun subjek tersebut. Dengan kata lain, fakta-fakta itu merupakan suatu hasil usaha seorang individu untuk memperoleh suatu keseimbangan yang baik dalam hubungannya dengan dunia sekitarnya (Faruk, 2014:56).

Sejalan dengan pendapat tersebut, Endraswara (2011:55) menyatakan bahwa semua aktivitas manusia merupakan respon dari subjek kolektif atau individu yang berada dalam situasi tertentu. Aktivitas tersebut merupakan hasil kreasi untuk memodifikasi situasi agar sesuai dengan aspirasi yang ada. Dalam konteks ini, manusia memiliki kecenderungan untuk berperilaku secara alami karena harus menyesuaikan situasi dengan lingkungan dan alam sekitarnya. Inilah makna dari fakta kemanusiaan tersebut.

\section{METODE PENELITIAN}

Jenis penelitian ini adalah penelitian kualitatif deskriptif (Sugiyono, 2014), yakni terhadap karya sastra berupa novel. Hal ini karena penjabaraan hasil yang diperoleh dijelaskan melalui kata, frase dan kalimat bukan melalui angka-angka (Ratna, 2013:46). Objek penelitiannya adalah novel Tere Liye yang berjudul Tentang Kamu. Data penelitian ini, berupa kata-kata, frasa, atau kalimat yang menunjukkan fakta kemanusiaan sebagai jejak sejarah PKI pada novel Tentang Kamu. Data penelitian ini dikumpulkan dengan metode telaah dokumen dengan teknik baca dan catat. Dalam hal ini, membaca semua sumber data (primer dan skunder) lalu mencatat data-data terkait masalah penelitian. Data dianalisis dengan menggunakan metode struktural genetik, yakni mengkaji karya sastra melalui sudut pandang ekstrinsik sosiologi historis. Analisis data dalam penelitian dengan metode strukturalisme genetik mengikuti tiga langkah kerja, yaitu: (1) mengkaji unsur intrinsik karya sastra baik secara parsial maupun dalam jalinan keseluruhannya, (2) mengkaji latar belakang kehidupan sosial budaya pengarang, dan (3) mengkaji latar belakang sosial budaya tempat sastra itu lahir (Iswanto, 2003; Siswantoro, 2010; dan Faruk, 2014).

\section{HASIL DAN PEMBAHASAN}

Setiap karya sastra memiliki unsur pembangun dalam pembentukannya. Salah satu unsur pembangun dimaksud adalah kondisi sosial masyarakat pendukungnya. Sebagai bagian dari masyarakat, pengarang tentu beraintraksi dengan masyarakat yang menghasilkan aktivitas-aktiviatas berbentuk fakta-fakta. Kondisi sosial masyarakat tidak lepas dari kejadian atau peristiwa dalam proses perjalanan sejarah (Wibowo, 2017). Peristiwa atau kejadian inilah yang memunculkan fakta-fakta kemanusiaan, baik yang verbal maupun nonverbal, dan yang bersifat individual maupun sosial (Faruk,2014). Sesuai dengan masalah pada tulisan ini, berikut disajikan pembahasan terkait fakta kemanusiaan pada novel Tentang Кати karya Tere Liye, yang mencerminkan sejarah pemberontakan PKI di Indonesia.

Tere Liye menggambarkan fakta-fakta dalam novelnya sebagaimana fakta yang sesungguhnya. Dalam hal ini dengan pilihan kata yang syarat dengan emosi. Beberapa fakta yang muncul terutama yang berkaitan dengan peristiwa pemberontakan PKI banyak bertebaran pada Bab Penghianatan I. Dalam bab ini, banyak ditemui fakta sosial 
meskipun tidak bisa dipungkiri ada juga yang memunculkan fakta individual. Fakta sosial seperti yang dikatakan oleh Faruk adalah fakta yang memiliki peranan dalam sejarah. Fakta kemanusiaan ini dapat berupa hubungan sosial, ekonomi dan politik (2014:57). Sehingga dalam penelitan ini pembahasan akan dilakukan lebih dalam pada fakta kemanusiaan yang berupa fakta sosial dalam tiga bentuk ini.

\section{Fakta Sosial berupa Hubungan Sosial}

Dalam novel ini tokoh Musoh yang semula adalah santri sekaligus menantu angkat yang dibanggakan, wakil dari sang kiyai, tiba-tiba berubah haluan. Pribadi yang dibanggakan akan membantu kiyai menjaga dan membangun pondok pesantren tiba-tiba berbalik arah sebagai pembenci dan memusuhi kiyai. Hal ini terjadi berawal dari kehadiran Arifin di pondok pesantren itu. Ia melamar Nuraini, anak pak kiyai setelah ia pulang dari Mesir. Setelah Arifin resmi menjadi menantu, banyak tugas pak kiyai dikerjakan olehnya. Bahkan kemudian ia ditunjuk untuk memimpin pondok putra menggantikan posisi Musoh. Rasa iri dan kecewa menggerogoti hati Musoh. Ia merasa dibuang oleh pak kiyai sehingga ia jarang mengikuti kegiatan pondok pesantren bahkan ia memutuskan keluar dari pondok pesantren

Untuk membalas dendam, Musoh mengikuti ormas beraliran kiri.

Musoh tidak puas hanya keluar dari pondok. Ia juga mempengaruhi Lastri, istrinya untuk membenci kiyai dan pondok pesantren. Lastri yang semula sangat menyayangi keluarga Kiyai Maksum terlebih Nuraini kini menjadi sangat membenci mereka. Tugasnya melatih tari dan ketoprak untuk santri putri, tidak lagi ia kerjakan.

Puncaknya, Musoh dan Lastri memimpin penculikan dan pembantaian pak kiyai, keluarga kiyai, dan santri-santri. Para santri dan keluarga pak Kiyai dibawa ke loji sebuah gudang tebu. Mereka disekap dan disiksa sebelum akhirnya gudang itu dibakar. Mereka tepanggang hidup-hidup di dalam loji itu. Kekejian yang dilakukan terhadap warga pondok ini tergambar pada penggalan teks berikut.

"Masukkan mereka kedalam loji" Sulastri berseru. Kiyai Ma'sum, istri dan anak-anaknya dihardik berdiri oleh orang-orang yang mengacungkan golok. Kemudian mereka didorong kasar, berjalan satu persatu menuju gudang tertutup. ... Kondisi Kiai Ma'sum mengenaskan, matanya terluka, dia tidak lagi bisa melihat sekitar. Lidahnya juga telah dipotong. Nyai kiai tak kalah menyedihkan, kebayanya penuh darah. Setelah semua anggota keluarga kiai Ma'sum dimasukkan ke dalam gudang,Sulastri melangkah keluar, sambil memberi perintah, "Tutup pintunya!" Pintu gudang berdebam ditutup. "Bakar!" (Liye, 2016:196).

Paparan imajinasi Tere Liye pada kalimat-kalimat di atas menjelaskan bagaimana hubungan sosial anatarwarga pondok sendiri. Musoh sebagai seorang guru bahkan bisa dianggap sebagai tangan kanan kiai Ma"sum tidak mampu menjelaskan ketidaknyamanannya, ketidakpuasannya kepada pimpinan pondok. Sehingga hal ini mengakibatkan munculnya rasa tidak adil pada dirinya. Hubungan baik yang sudah tercipta tak mampu ia pelihara hanya karena ketidakmampuannya dalam mengomunikasikan sebagai wujud hubungan sosial yang baik. Bahkan rasa ini membawa ia menempuh jalan yang berlawanan sebagai wujud ketidakpuasan dan perlawanannya terhadap keputusan-keputusan dan tindakantindakan pimpinan pondok.

Cara melawan yang digunakan oleh tokoh Musoh sering kali ditemukan pada masyarakat Indonesia. Ketidakpuasan terhadap kebijakan-kebijakan pimpinan seringkali diungkapkan dengan tindakan keluar dari kelompoknya. Bahkan kemudian menjadikan dirinya rival atau lawan. Khusus untuk pondok pesantren, rasa memiliki membuat mereka memiliki hubungan sosial yang kuat anatara satu orang dengan orang 
lain. Tetapi tidak sedikit yang melakuka tindakan seperti yang dilakukan Musoh. Meninggalkan kelompoknya kemudian mendirikan kelompok lain dengan faham yang berbeda bahkan bertentangan dengan kelompok sebelumnya.

\section{Fakta Sosial berupa Hubungan Ekonomi}

Selain fakta kemanusiaan yang berwujud hubungan sosial, pada novel ini juga terdapat fakta sosial yang berwujud ekonomi. Persoalan-persoalan ekonomi terutama pada masa-masa tahun 1965 sangat carut marut. Meski demikian, pada pondok pesantren masih punya cara sendiri untuk memenuhi kebutuhan santrinya.

Pondok biasanya punya sistim ekonomi sendiri yang dikelola bersama warga pondok lainnya. Seperti yang tanpak pada kutipan berikut.

Tilamuttha tertawa menjelaskan jika ia ikut murid laki-laki lain membajak sawah milik madrasah (Liye,2016:157).

Cara mengatur perekonomian pondok bisa diperhatikan pada teks di atas bahwa pondok melakukan kerja sama dengan para santri untuk mengelola aset yang dimiliki pondok. Pengelolaan ini untuk kepentingan pondok beserta warganya. Namun pada novel ini dijadikan sebagai alat untuk menghasut orang lain untuk membenci pimpinan pondok pesantren. Hal ini dapat dilihat pada kutipan di bawah ini.

"Apa susahnya kamu melihatnya, Sri. Dia hanya ongkang kaki di rumah bagusnya, tapi santrinya bekerja siang malam untuknya

"Tapi pak Kiai juga bekerja di sawah kan, Mas? Kita semua melihatnya. santri juga digeratiskan tinggal di madrasah, bisa makan, bisa tidur. Juga dapat uang saku" (Liye,2016:185).

Pengaturan ekonomi seperti ini masih berlaku sampai sekarang terutama pada pondok pesantren yang letaknya berada di pedesaan. Pengelolaan perekonomian ini bukan hanya mengefesiankan pemasukan dan pengeluaran tetapi sekaligus mendidik peserta didik atau santri untuk bekerja dan menerapkan ilmunya secara nyata sehingga mereka memiliki keahlian tersendiri. Bahkan pada saat ini, model pendidikan seperti ini lebih dikembangkan dengan istilah yang berbeda yang biasa disebut dengan life skill. Tetapi pada novel ini, hal ini dijadikan senjata untuk menyerang kaum ulama, kiai dan pemilik pondok pesantren agar mendapat simpati dari kaum buruh dan tani. Menanamkan faham komunis, di mana tidak ada perbedaan kelas dalam pengaturan ekonomi. Seolah-olah kelompok orang kaya, kiai, ulama dan para priyayi atau biasa mereka sebut kaum borjuis memperbudak para buruh dan tani.

Merasa nasib mereka diperhatikan dan diperjuangkan, buruh dan tani mudah termakan hasutan kelompok ini. Sehingga pada pemilihan umum pada tahun itu, PKI memeperoleh cukup banyak pengikut dan simatisan. Bahkan partai ini mendududki urutan pertama pada pemilu tersebut.

\section{Fakta Sosial berupa Hubungan Politik}

Politik sering kali menjadi topik yang menarik untuk dijadikan pesoalan dalam sebuah novel. Dalam perjalanan sebuah bangsa, politik menjadi bagian penting untuk mewujudkan bangsa yang besar. Hanya saja politik terkadang menjadi kejam ketika berada pada pemikiran, gagasan dan faham yang salah. Pada novel Tentang Кати, politik banyak dibahas pada bab Penghianatan. Pembahasan ini terutama berkaitan dengan pergerakan faham komunis di Indonesia.

Tahun-tahun itu, tanpa Sri sadari, gejolak politik tengah panas-panasnya di pulau Jawa, Itu tinggal hitungan bulan dari meletusnya pemberontakan besar akhir September 1965, saat kelompok yang menamakan dirinya Partai Komunis Indonesia (PKI) berusaha habis-habisan menyusun rencana mengambil alih kekuasaan yang sah. Itu bukan penghianatan pertama kelompok ini atas negara Indonesia, setelah mereka menusuk dari belakang tahun 1948 . (Liye: 2016: 181). 
Penggalan novel di atas bukan lagi sebagai imajinasi Tere Liye semata, tetapi lebih pada paparan sejarah. Pada tahun 1965, gejolak politik di Indonesia memang sedang pada puncak krisis. Perebutan pengaruh dan kekuasaan anatar elit politik semakin tak terkendali. Penanaman pengaruh antara partai komunis dengan TNI terhadap kepiemimpinan presiden Soekarno semakin tajam. Persaingan yang tidak sehat untuk memperoleh pengikut semakin jelas terlihat. Bahkan perebutan ini diwarnai pertumpahan darah anak bangsa sendiri.

Pertikaian, gesekan, bahkan benturan mulai terjadi diberbagai daerah. Provokasi setiap hari dilakukan, kebencian terhadap agama terus digemakan, seolah semua kiai adalah orang jahat munafik. Siapapun berbicara agama maka ia sok suci (Liye, 2016:188).

Peperangan yang digenderangkan oleh kelompok komunis terhadap agama dan kalangan priyayi juga orang kaya terus berlanjut. Penyebaran kata-kata kebencian terus digemakan sebagai bentuk gerakan verbal untuk memperoleh pengikut dan simptisan.

Selain slogan-slogan dan jargon yang merupakan tindakan pertikaian secara verbal, banyak pula tindakan-tindakan fisik yang dilakukan kelompok ini. Tokoh Musoh sebagai penggambaran pemimpin kelompok kiri ini, memimpin penculikan dan pembunuhan kelompok agama yaitu kiai Ma'sum beserta keluarga dan para santrinya. Hal ini dilakukan sebagai bentuk balas dendam dan perlawanan terhadap kelompok pondok pesantren yang dianggapnya tidak adil dan memeras keringat para santri. Pada dasarnya tindakan ini semata-mata karena perbedaan aliran dan faham pemikiran politik. Tindakan-tindakan ini tergambar pada kutipan di bawah ini.

Saatnya kami menghabisi tuan tanah, para kiai, dan militer. Kami akan menyerang madrasah kiai Ma'sum malam ini. Siapapun yang ada disana akan dihabusi. (Liye, 2016:189).

Paparan imajinasi Tere Liye pada kalimatkalimat di atas menjelaskan bagaimana perlakuan PKI sebagai sebuah organisasi masa bahkan partai pada masa tahun 1948 maupun 1965. Saat itu PKI dipimpin oleh Muso melakukan pemberontakan dengan menyerang dan menyekap serta membunuh pimpinan dan tokoh pesantren terutama di daerah Madiun, basis PKI pimpinan Muso. Perbuatan-perbuatan ini sebagai bentuk fakta kemanusiaan yang bersifat sosial non verbal. Fakta ini telah tercatat dalam sejarah, baik berupa tulisan maupun saksi hidup. Seperti penjelasan berikut.

Salah satu korban keganasan PKI yang masih hidup adalah $\mathrm{KH}$ Roqib. Kini $\mathrm{KH}$ Roqib adalah imam besar Masjid Jami' Baitussalam Magetan. Beliau menceritakan tentang kebencian PKI terhadap apapun yang bernuansa agama. Salah satu unsur umat Islam yang juga paling dibenci PKI adalah Masyumi.

Sebagai salah seorang kyai yang juga tokoh Masyumi, Roqib pun menjadi sasaran yang harus dilenyapkan. Dia diculik PKI pada tanggal 18 September 1948 sekitar pukul 03.00 dini hari, tak lama setelah PKI merebut kota Madiun. Belaiu diculik oleh anggota PKI sebanyak 12 orang dengan pakaian hitam dan ikat kepala merah. KH Roqib diciduk di rumah kediamannya di kampung Kauman, Magetan. Dini hari itu juga dia dibawa ke Desa Waringin Agung dan disekap di sebuah rumah warga.

KH Roqib dibawa ke sebuah dusun bernama Dadapan yang termasuk dalam wilayah Desa Bangsri. Dia diseret oleh beberapa orang ke sebuah lubang di tengah ladang. Ketika dia akan disembelih di depan lubang, tiba-tiba Sang kiai mengingat pelajaran pencak silat yang diperolehnya. Seketika itu dia menghentakkan kakinya dan meloncat lari ke kebun singkong. Dia lari sekencang-kencangnya sampai menjauh dari para penculiknya. Begitu dia lolos, Roqib bersembunyi di antara rerimbunan semak belukar hingga siang hari. Naas, siang itu pula dia ditemukan kembali oleh anggota PKI yang mengejarnya. Roqib pun tertangkap dan diikat lagi, lalu disiksa sepanjang jalan dari Desa Bangsri hingga pabrik gula GorangGareng. 
Di pabrik gula Gorang-Gareng, Roqib disekap dalam sebuah loji (rumah-rumah besar untuk asrama karyawan). Di dalam loji terdapat banyak kamar dengan berbagai ukuran. "Ketika saya datang ke loji itu, kamar-kamarnya sudah penuh dengan tawanan. Satu kamar ukuran 3 x 4 meter diisi kurang lebih 40-45 orang. Bersama 17 orang lainnya, saya dimasukkan ke dalam salah satu kamar yang terdapat di ujung loji," tutur Roqib.

PKI kemudian menembaki loji tempat Roqib dan tawanan lainnya disekap lebih dari satu jam lamanya. Tubuh-tubuh yang terkena peluru langsung terkapar di lantai bersimbah darah. PKI tidak mempedulikan teriakan histeris para korban yang terkena peluru. Mereka terus saja melakukan tembakan. Di antara belasan orang yang ada di dalam loji, hanya Roqib dan Salis, serta seorang tentara bernama Kafrawi, yang selamat. Menurut guru ngaji ini, setiap habis menembak, pistol yang digunakan PKI itu tidak bisa menembak lagi, tapi harus dikokang dulu. "Saya bisa selamat dari tembakan karena memperhitungkan jeda waktu antara tiap tembakan sambil bersembunyi di bawah jendela. Kalau tanpa pertolongan Allah, tidak mungkin saya selamat," kata Roqib getir.(http://www.ittibaussalaf.com/2016/05).

Selain pimpinan pondok, kiai dan santri, PKI juga menamgkap dan membunuh aparat pemerintah. Siapapun yang menentang dan berlawanan pendapat dengan PKI menjadi sasaran kebiadabannya. Apa yang digambarkan Tere Liye pada novel Tentang Kamu dengan tokoh yang berbeda dan dan latar tempat yang samarkan tetap memberi jejak prilaku PKI pada masa silam. Seperti yang diungkap oleh Hanif berikut.

Letak desa Soco cukup strategis, di samping dekat lapangan Udara Iswahyudi, juga dilintasi re-rel kereta Lori dari daerah perkebunan tebu menuju berbagai pabrik gula seperti pabrik gula Pagotan, Kanigoro, Glodok dan Pabrik gula Rejosari di Gorang-gareng. Di desa Soco terdapat sumur-sumur tua di tengah tegalan yag sangat memungkinkan untuk dipakai sebagai lubang pembantaian karena letaknya jauh dari pemukiman penduduk. Sebelum peristiwa berdarah itu terjadi, warga masyarakat desa Soco sudah mulai merasakan adanya aksi-aksi yang dilakukan oleh orang-orang PKI; pencurian, perampokan dan penculikan berlangsung dengan semena-mena, yang menjadi korban senantiasa orang-orang yang bukan PKI. Kejadian itu mencapai puncaknya pada tanggal 18 September 1948. Pada tahun ini terjadi pembantain PKI. Sumur-sumur tua di Soco tersebut dirancang sedemikian rupa oleh PKI dijadikan basis untuk membantai para tokoh yang dianggap lawan, seperti Bupati Magetan Sudibjo, Kapten Soebarin, Jaksa R. Moerti, Muhammad Suhud (Ayahanda Kharis Suhud), Kapten Sumarno, Suratatim, KH. Muhammad Noer, serta aparat pamerintah Republik Indonesia lain yang berhasil mereka tawan itu dibantai. Di Soco terdapat dua buah sumur tua yang dipakai sebagai lubang pembantaian oleh FDR/PKI, dan keduanya terletak tidak jauh dari jalur rel kereta lori pengangkut tebu. Para tawanan yang disekap di Pabrik gula Rejosari secara bergiliran diangkut dengan gerbong lori. Dari jalur Rejosari itulah gerbong-gerbong lori diarahkan ke jurusan desa Soco dan desa Cigrok yang merupakan lubang-lubang pembantaian. Menurut seorang saksi bernama Soepardi, pada waktu itu Lurah Belotan yang bernama Darmo melaporkan ke tangsi polisi ikhwal masuknya FDR/PKI di desanya. Beberapa saat kemudian, Soepardi melihat Lurah tersebut beserta cariknya digiring oleh FDR/PKI ke sumur Soco untuk dibantai (Hanif, 69-70).

Jauh sebelumnya, PKI juga sudah pernah melakukan pemberontakan. Pada tahun 1926-1927, PKI melakukan pemberontakan pertama di Jawa, tetapi dikecam oleh kominterm juga pemimpinpemimpin mereka yang ada di pengasingan apalagi pemberontakan ini mengalami kegagalan (Ricklefs, 2008:271). Pemberontakan ini berawal karena adanya 
perselisihan di kalangan petinggi partai tentang cara melancarkan perjuangan.

Selain fakta kemanusiaan dalam bentuk sosial nonverbal, ada beberapa fakta politik dalam bentuk verbal yang terdapat pada novel ini. Salah satunya adalah ungkapan-ungkapan yang disampaikan oleh kelompok PKI. Ungkapan-ungkapan ini menyudutkan dan mengecilkan kelompok tertentu terutama kelompok agama atau pondok pesantren. Hal ini dijelaskan pada kutipan di bawah ini.

Singkirkan para munafik! tuan tanah1

Para Kiai!. Para penonton kembali mengepalkan tinju ke udara. "Baik sebagai hiburan malam ini, mari kita sambut ludruk dengan lakon 'Matine Gusti Allah'.” (Liye, 2016: 186 ).

Ungkapan ini menjadi jargon yang sering dijadikan senjata oleh kelompok PKI untuk menarik masa terutama kaum buruh dan tani. Karena Objek dan basis kampanye komunis memang berada pada kelompok ini bukan hanya di Indonesia bahkan seluruh dunia. Kemiskinan dan kekurangan yang dialami oleh sebagaian besar kelompok ini menjadi hal yang mampu menggeret mereka untuk dengan mudah tertarik mengikuti faham ini. Selain faham ini membawa penderitaan mereka sebagai misi utama untuk menuntut keadilan, masalah-masalah kesamaan dan pemerataan antara kaum proletrar yang diwakili kaum buruh dan tani dengan kaum borjuis yang diidentikan dengan orang-orang kaya dan sejahtra terutama kaum priyayi, kiai dan TNI.

Fakta-fakta ini tak bisa dipungkiri kebenarannya. Selain diungkapkan dalam bentuk tulisan sejarah, saksi-saksi hidup yang mengalami langsung kejadian tersebut tak mampu melupakan perbuatan PKI terhadap mereka khususnya dan rakyat Indonesia umumnya. Kebiadaban dan kekejian tindakan mereka bahkan dibuatkam monumen untuk mengabadikannya. Bahkan segala media dimasuki untuk mengingatkan termasuk film dan novel. Salah satu novel itu adalah karya Tere Liye Tentang Кати. Tere Liye mengambil sejarah pemberontakan PKI ini sebagai lintasan perjalanan tokoh Sri, sekaligus ingin menukil sejarah agar peristiwa tersebut tidak dilupakan dan lenyap dalam perjalanan bangsa. Penyampaian yang dipilih Tere Liye melalui novel dengan tambahan imajinasi memberikan warna lain dalam pemahaman perjalanan sejarah bangsa Indonesia.

\section{SIMPULAN}

Berdasarkan paparan hasil dan pembahasan diketahui bahwa fakta kemanusiaan dalam novel Tentang Кати karya Tere Liye yang mencerminkan sejarah PKI dominan berupa fakta sosial, yakni berupa hubungan sosial, ekonomi, dan politik. Dalam hal ini ada yang berupa verbal dan ada pula yang berupa nonverbal. Disimpulkan bahwa: (1) Fakta sosial berupa hubungan sosial tercernin pada kisah penculikan dan pembantaian kiyai, keluarga kiyai, dan santri-santri pondok pesantrean oleh Musoh dan Latri karena ketidakpuasannya terhadap kebijakan kiayai Ma'sum, padahal sebelumnya mereka adalah orang kepercayaan kiyai Ma'sum; (2) Fakta sosial berupa hubungan ekonomi tercernin pada kisah pengaturan perekonomian pondok pesantren yang dijadikan alat untuk menghasut orang lain agar membenci pimpinan pondok pesantren dan melakukan pemberontakan; dan (3) Fakta sosial berupa hubungan politik tercernin pada kisah pergerakan faham komunis di Indonesia tahun 1948-1965, perebutan pengaruh dan kekuasaan anatar elit politik TNI dan PKI yang tak terkendali, dan penyebaran katakata/slogan kebencian oleh kelompok PKI.

\section{SARAN}

Sesuai dengan temuan penelitian ini, terdapat beberapa hal yang patut dikemukakan sebagai saran. Hal-hal dimaksud adalah: (a) kepada para peneliti berikutnya, terutama yang meneliti masalah karya sastra sebaiknya lebih banyak menggunakan metode strukturalisme genetis karena metode ini lebih komprehensif, yakni memandang dan menganalisis karya sastra dari berbagai sudut pandang; dan (b) kepada 
para guru bahasa Indonesia di SMA sebaiknya menggunakan hasil kajian semacam ini sebagai landasan pengembangan bahan ajar berupa teks cerita sejarah. tentu saja setelah direkonstruksi dan direstrukturisasi berdsarkan struktur dan kebahasaan teks cerita sejarah.

\section{UCAPAN TERIMAKASIH}

Ucapan terimakasih terutama disampaikan kepada Prodi Pascasarjana Pendidikan Bahasa Indonesia FKIP Unram yang telah memfasilitasi terselenggaranya penelitian ini. Ucapan terima kasih juga disampaikan kepada pembimbing I dan pembimbing II, yang telah membantu peneliti menyelesaikan semua rangkain penelitian ini.

\section{DAFTAR PUSTAKA}

Damono, Sapadi Djoko. 2009. Sosiologi Sastra: Sebuah Pengantar Ringkas. Jakarta: Pusat Pembinaan dan Pengembangan Bahasa Depdikbud

Endraswara, Suwandi. 2011. Metodologi Penelitian Sosiologi Sastra. Yogyakarta. CAPS

Fananie, Z. (2000). Telaah Sastra. Surakarta: Muhammadiyah University Press.

Faruk. 2002. Kelangsungan: Hubungan Teori dengan Kritik Sastra Indonesia. Majalah Horison edisi XXXV, Januari, hal. 9-19.

. 2014. Pengantar Sosiologi Sastra: dari Strukturalisme Genetik sampai Post-Moderenisme.

Yogyakarta:Pustaka Pelajar

Hanif, M. (2011). Peranan Wanita Desa Soco Bendo Magetan Dalam Mengatasi Dampak Psikologi Sosial Pasca Madiun Affair 1948 (Studi Sejarah Sosial). AGASTYA: JURNAL SEJARAH DAN PEMBELAJARANNYA, 1(1), 63-82.

Iswanto. 2003. "Penelitian Sastra dalam Perspektif Strukturalisme Genetik" dalam Metodologi Penelitian Sastra (Jabrohim, ed.). Yogyakarta: Hanindita Graha Widya.

Liye, Tere. 2014. Rindu. Jakarta: Republika
Liye, Tere. 2015. Sanset dan Rosie. Jakarta: Republika

Liye, Tere. 2016. Tentang Кати. Jakarta: Republika

Liye, Tere. 2018. Anak Cahaya. Jakarta: Republika

Ratna, Ny. Kunta. 2013. Teori, Metode, dan Teknik Penelitian Sastra. Yogyakarta: Pustaka Pelajar

Ricklefs, M.C., 2008. A History of Modern Indonesia Since c.1200 (Third Edition). Basingstoke:PALGRAVE

Rokhman, M. A. (2008). Keterkaitan Kajian Budaya dan Studi Sastra di Inggris: Sebuah Telaah Singkat. Jurnal Humaniora, 20(1), 18-25.

Siswantoro. 2010. Metode Penelitian Sastra. Yogyakarta: Pustaka Pelajar.

Sitepu, Gustaf. 2009. Strukturalime Genetik Asmaraloka. Tesis tidak dipublikasikan. PPS Universitas Sumatra Utara

Sugiyono. 2014. Metode Penelitian Pendidikan Pendekatan Kuantitatif, Kualitatif dan $R$ \& $D$. Bandung: Alfabeta

Wibowo, Erwin. 2017. Kajian Nilai-nilai Historisme dalam Novel Trilogo Soekram Karya Sapardi Joko Damono. Jurnal Kibas Cendrawasih Vol. 14 (2). Hal 209 -220 